\title{
IMPLEMENTASI PEMBELAJARAN MODEL KOOPERATIF TIPE TWO STAY TWO STRAY UNTUK MENINGKATKAN HASIL BELAJAR SISWA DI SMP PLUS MIFTAHUL ULUM SUMENEP
}

\author{
Dyah Ayu Fajarianingtyas ${ }^{1}$, Herowati $^{2}$ \\ Universitas Wiraraja ${ }^{1,2}$ \\ tanzilkurnain@gmail.com ${ }^{1}$, heromukmin@yahoo.co.id ${ }^{2}$
}

\begin{abstract}
ABSTRAK
Hasil observasi di SMP Plus Miftahul Ulum Tarate Sumenep menunjukkan bahwa penggunaan model pembelajaran yang bervariasi belum banyak dilakukan sehingga siswa kurang aktif dan hasil belajar siswa rendah. Berdasarkan hasil observasi di SMP Plus Miftahul Ulum Tarate Sumenep, menunjukkan bahwa penggunaan metode pembelajaran belum bervariasi dan hasil belajar IPA siswa kelas VII SMP Plus Miftahul Ulum Tarate Sumenep masih rendah. Penerapan pembelajaran model koopertif two stay two stray menjadi alternatif untuk dapat meningkatkan keterlibatan dan prestasi belajar siswa dalam pembelajaran IPA. Tujuan Penelitian ini untuk meningkatkan aktivitas belajar siswa dan hasil belajarnya. Penerapan model pembelajaran kooperatif two stay two stray menggunakan prinsip penelitian tindakan kelas, yaitu: perencanaan (planning), tindakan (action), observasi (observation), refleksi (reflection) atau evaluasi. Teknik analisis data dengan teknik persentase. Hasil belajar siswa meningkat pada siklus I sebesar 10,10 Nilai rata-rata siswa meningkat dari 56,26 (pretes) menjadi 66,36 (posttest). Pada siklus II hasil belajar siswa meningkat sebesar 17,10 dari 59,32 (pretes) menjadi 76,42 (posttest). Peningkatan hasil belajar siswa tersebut menunjukkan bahwa model kooperatif tipe two stay two stray dapat digunakan untuk memperbaiki kegiatan pembelajaran.
\end{abstract}

Kata Kunci : pembelajaran kooperatif, two stay two stray (TSTS), penelitian tindakan kelas, hasil belajar

\section{PENDAHULUAN}

Salah satu faktor penentu keberhasilan proses belajar mengajar adalah dengan menerapkan strategi atau pendekatan pembelajaran yang efektif dan efisien. Tujuan pembelajaran secara efektif dapat dicapai bila proses belajar mengajar siswa untuk mendapatkan pengetahuan dan pengalaman belajar bermakna. Hal ini dapat dicapai bila dalam pembelajaran melibatkan partisipasi aktif siswa (Bektiarso, 1997:194).

Berdasarkan hasil observasi di SMP Plus Miftahul Ulum Tarate Sumenep, menunjukkan bahwa penggunaan metode pembelajaran belum bervariasi dan hasil belajar IPA siswa kelas VII SMP Plus
Miftahul Ulum Tarate Sumenep masih rendah.

Nilai rata-rata ulangan harian mata pelajaran IPA semester 1 Tahun Ajaran 2014/ 2015 SMP Plus Miftahul Ulum Tarate Sumenep. Kelas VII A untuk ulangan pertama adalah 50 dan ulangan ke kedua 55,5. Kelas VII B untuk ulangan pertama adalah 48 dan ulangan ke kedua 50, dan kelas VII C untuk ulangan pertama adalah 48,5 dan ulangan ke kedua 56.

Rendahnya perolehan hasil belajar mata pelajaran IPA menunjukkan rendahnya kinerja belajar siswa dan kemampuan guru dalam mengelola pembelajaran yang berkualitas. Untuk mengetahui mengapa prestasi siswa tidak seperti yang diharapkan, tentu guru perlu 
merefleksi diri untuk dapat mengetahui faktor-faktor penyebab ketidak berhasilan siswa dalam pelajaran IPA. Sebagai guru yang baik dan profesional, permasalahan ini tentu perlu ditanggulangi dengan segera.

Berdasarkan hal tersebut diatas, penerapan pembelajaran koopertif model two stay two stray menjadi alternatif untuk dapat meningkatkan prestasi belajar siswa dalam mata pelajaran IPA. Penelitian ini memiliki tujuan sebagai berikut:

1. Mengetahui penerapan pembelajaran kooperatif two stay two stray (TSTS) pada pokok bahasan keaneragaman makhluk hidup.

2. Meningkatkan aktivitas siswa dalam pembelajaran kooperatif two stay two stray (TSTS).

3. Mengetahui hasil belajar siswa setelah mengikuti pembelajaran kooperatif model Two stay two stray (TSTS) pada pokok bahasan keaneragaman makhluk hidup?

4. Mengetahui hambatan-hambatan yang muncul selama diterapkannya pembelajaran kooperatif model Two stay two stray (TSTS).

\section{TINJAUAN PUSTAKA}

\section{Pembelajaran Model Kooperatif Tipe} Two Stay Two Stray (TSTS)

Pembelajaran kooperatif adalah pembelajaran yang secara sadar dan sistematis mengembangkan interaksi yang silih asah, silih asih, dan silih asuh antar sesama siswa sebagai latihan hidup di dalam masyarakat nyata" Abdurrahman dan Bintaro (dalam Nurhadi, Yasin dan Senduk, 2004:61). Menurut Ibrahim, dkk (2002:2) "pembelajaran kooperatif merupakan pembelajaran yang ditandai dengan struktur tugas, struktur tujuan, dan struktur penghargaan (reward)".

Salah satu model pembelajaran kooperatif adalah two stay two stray. Menurut Riyanto (2009:281) langkah- langkah model dua tinggal dua tamu adalah sebagai berikut: 1) satu kelompok beranggotakan empat siswa; 2) beri tugas untuk berdiskusi; 3) setelah selesai, dua siswa bertamu ke kelompok lain; 4) dua siswa yang tinggal menginformasikan diskusinya kepada dua tamu; 5) tamu kembali kekelompok dan melaporkan temuan mereka dari kelompok lain. Menurut Rudyanto (2005:77) langkahlangkah dalam menerapkan model Two stay two stray adalah sebagai berikut: 1) siswa bekerjasama dalam kelompok bertiga, berempat atau lebih; 2) setelah selesai, dua orang dari masing-masing kelompok akan meninggalkan kelompoknya dan masing-masing bertemu kedua kelompok yang lain untuk saling berkomunikasi; 3) dua orang yang tinggal dalam kelompok bertugas membagikan hasil adalah sebagai berikut: 1) siswa bekerjasama dalam kelompok bertiga, berempat atau lebih; 2) setelah selesai, dua orang dari masing-masing kelompok akan meninggalkan kelompoknya dan masing-masing bertemu kedua kelompok yang lain untuk saling berkomunikasi; 3) dua orang yang tinggal dalam kelompok bertugas membagikan hasil kerja dan informasi mereka kepada tamu yang berkunjung ke kelompok lainnya; 4) tamu mohon diri dan kembali ke kelompok mereka sendiri dan melaporkan temuan mereka dari kelompok lain; 5) kelompok mencocokkan dan membahas hasil-hasil kerja mereka.

Kelebihan model Two stay two stray adalah: 1) dapat menambah kemampuan berpikir sendiri, menemukan informasi dari berbagai sumber, dan belajar dari siswa lain; 2) mengembangkan kemampuan mengungkapkan ide secara verbal dan membandingkan dengan ide-ide orang lain; 3) membantu siswa untuk menghargai orang lain; 4) siswa dapat memecahkan permasalahan untuk menguji pemahamannya. Sedangkan kelemahan model Two stay two stray 
adalah: 1) memerlukan waktu yang banyak; 2) bagi guru, memerlukan persiapan yang matang; 3) guru cenderung kesulitan dalam pengelolaan kelas.

Dari beberapa penjelasan di atas dapat disimpulkan model pembelajaran Two stay two stray adalah model pembelajaran kooperatif dimana siswa bekerjasama dalam kelompok secara heterogen. Siswa saling berkunjung, baik sebagai tamu maupun tuan rumah untuk bertukar informasi kemudian mempresentasikan hasil diskusinya di depan kelas. Dengan adanya model Two stay two stray diharapkan siswa dapat mengembangkan kemampuan sosialnya

\section{Belajar Tuntas (Mastery Learning)}

Salah satu asas mengajar yang kita kenal "asas perbedaan individual". Kaitan asas ini dalam praktek belajar mengajar telah lama dipikirkan para ahli kependidikan tentang bentuk-bentuk pengajaran yang dapat memberi kesempatan kepada siswa belajar secara individual.

Berbagai hasil penelitian membuktikan bahwa kemampuan dasar atau kemampuan potensial (intelejensia dan bakat) seseorang berbeda satu sama lain. Tidak ada individu mempunyai intelejensia ataupun bakat yang sama dalam berbagai bidang. Meskipun kita terima pengelompokan siswa berdasarkan kategori prestasi tinggi-sedang-rendah, itu hanyalah suatu pendekatan saja. Hakekatnya setiap siswa berbeda secara individual, baik dalam hal prestasi hasil belajar maupun kemampuan potensial.

Menekankan

pentingnya memperhatikan perbedaan individual dalam pengajaran, sungguh suatu keharusan. Namun demikian dalam praktek belajar mengajar hal ini masih merupakan sesuatu yang ideal. Untuk mewujudkannya guru harus memahami dan mampu mengembangkan strategi belajar mengajar dengan pendekatan individual.
Strategi belajar individual disamping memungkinkan setiap siswa dapat belajar sesuai dengan kemampuan potensialnya, jika memungkinkan setiap siswa dapat menguasai seluruh bahan pelajaran secara penuh. Kemampuan memperoleh hasil secara penuh ini merupakan ide tersendiri yang melandasi berbagai sistem pengajaran individual. Ide ini dikenal dengan istilah "Mastery Learning atau Belajar Tuntas”.

Dalam bukunya berjudul Belajar Tuntas (mastery learning), Marsandi berpendapat bahwa belajar tuntas (mastery learning) adalah suatu sistem belajar yang mengharapkan sebagian besar siswa dapat menguasai tujuan instruktional umum (basic learning objectives) dari satuan-satuan atau unit pelajaran secara tuntas (Marsandi, 1978:1).

Menurut Ali (1984:75) belajar tuntas dapat diartikan sebagai penguasan (hasil belajar) siswa secara penuh terhadap seluruh bahan yang dipelajari. Hal ini berlandaskan kepada suatu gagasan bahwa kebanyakan siswa dapat menguasai apa yang diajarkan di sekolah, bila pengajaran dilakukan secara sistematis. Dalam taraf penguasaan penuh pada seluruh siswa tanpa kecuali, pembelajaran harus dilakukan secara sistematis. Kesistematisan proses tersebut tercermin dari strategi pembelajaran yang dilaksanakan. Patokan yang digunakan sebagi standar penguasaan penuh biasanya cukup tinggi. Berkisar antara $75 \%$ atau $80 \%$ sampai dengan $90 \%$. Dapat dibayangkan, penguasaan minimalpun sudah dikatakan cukup tinggi. Peluang untuk mencapai taraf kemampuan lebih tinggi dari itu sangat besar. Juga tidak ada lagi siswa memperoleh hasil belajar rendah, karena yang mendapat hasil rendah diberi bantuan secukupnya sehingga mencapai taraf penguasaan penuh. Pada evaluasi akhir programpun siswa memperoleh prestasi tinggi pula. 
Strategi belajar tuntas dapat diterapkan secara tuntas sebagai upaya peningkatan mutu pendidikan, terutama dalam level mikro, yaitu mengembangkan individu dalam proses pembelajaran di kelas. Hal ini tidak menuntut perubahan besar-besaran baik dalam kurikulum maupun dalam pembelajaran, tetapi yang penting adalah mengubah strategi guru yang berhubungan dengan waktu. Perhatian guru terhadap waktu, bukan waktu yang dibutuhkan untuk mengajar melainkan waktu yang digunakan peserta didik untuk belajar sampai pada taraf penguasaan bahan sepenuhnya (belajar tuntas).

Ide belajar tuntas ditopang oleh situasi dasar bahwa semua atau hampir semua siswa dapat menguasai apa yang diajarkan kepadanya, bila proses pembelajaran dilaksanakan secara sistematis dan tingkat keberhasilan siswa di sekolah ditentukan oleh kemampuan bawaan atau bakat yang dimilki masingmasing (Wahyuni, 2002:15).

Ide belajar tuntas sebagaimana dikemukakan di atas, melandasi sistem belajar individual. Implementasi pengajaran individual dapat dilihat dalam berbagai bentuk sistem pengajaran individual. Hal ini berarti bahwa implementasi strategi belajar tuntas tidak selamanya berbentuk sistem belajar individual. Karena strategi belajar tuntas tertentu diselenggarakan dalam sistem pengajaran biasa, meskipun hasil yang dicapainya bersifat individual, terutama dalam hal penguasaan penuh bahan pengajaran. Namun demikian, karena sistem pengajaran individual selalu dilaksanakan dalam rangka mencapai taraf penguasaan penuh bahan yang dipelajari siswa maka sistem pengajaran individual dapat merupakan salah satu strategi belajar tuntas.

\section{Hasil belajar}

"Belajar merupakan tindakan dan perilaku siswa yang kompleks" (Dimyati dan Mudjiono, 2002:7). Sedangkan menurut Slameto (2003:2) belajar adalah suatu proses usaha yang dilakukan seseorang untuk memperoleh suatu perubahan tingkah laku yang baru secara keseluruhan, sebagai hasil pengalaman sendiri dalam interaksi dengan lingkungannya.

Menurut Dimyati dan Mudjiono (2003:3) "hasil belajar adalah hasil dari suatu interaksi tindak belajar dan tindak mengajar". Hasil belajar tersebut dapat dibedakan menjadi dampak pengajaran dan dampak pengiring. Dampak pengajaran adalah suatu hasil yang dapat diukur seperti tertuang dalam angka rapot dan angka dalam ijazah. Sedangkan dampak pengiring adalah terapan pengetahuan dan kemampuan dibidang lain. Oleh sebab itu, pada hakekatnya hasil belajar adalah perubahan tingkah laku sebagai hasil dari proses belajar mengajar. Perubahan itu dapat berupa pengetahuan, pemahaman, keterampilan dan sikap. Sedangkan Bloom dalam Abdullah mengklasifikasikan hasil belajar dalam tiga ranah yaitu: ranah kognitif, ranah afektif dan ranah psikomotorik. Ranah kognitif meliputi pengetahuan, penerapan, pemahaman, analisi, sintesis, dan evaluasi. Ranah afektif meliputi reaksi, penilaian, organisasi dan internalisasi. Ranah psikomotorik meliputi peniruan, ketelitian dan pengurutan kegiatan serta penghayatan.

\section{METODE PENELITIAN}

Dalam penelitian ini yang menjadi subyek penelitian adalah siswa kelas VIIB SMP Plus Miftahul Ulum Tarate Sumenep sebanyak 38 siswa. Penentuan subyek penelitian menggunakan teknik populasi, karena penelitian tindakan kelas sampelnya berbentuk populasi. Penelitian ini merupakan penelitian tindakan kelas (Classroom Action Reseach) yang dilaksanakan berdasarkan prinsip Kemmis dan Toggar (1988) yaitu: 
perencanaan (planning), tindakan (action), observasi (observation), refleksi (reflection) atau evaluasi. Keempat kegiatan ini berlangsung sebanyak 2 siklus. Penelitian Tindakan Kelas ini terdiri atas dua siklus kegiatan.

Dari tahap kegiatan pada siklus I dan II, hasil yang diharapkan adalah: 1) Siswa selalu aktif terlibat dalam proses pembelajaran IPA; 2) Guru memiliki kemampuan merancang dan menerapkan pembelajaran kooperatif model Two stay two stray (TSTS); 3) Terjadi peningkatan prestasi siswa pada mata pelajaran IPA.

Teknik analisis data pada penelitian ini bersifat kualitatif tdengan teknik persentase sebagaimana hakekat PTK. Namun data-data kuantitatif tidak berarti diabaikan, akan tetapi digunakan sebagai pelengkap dalam melakukan analisis kualitatif.

\section{HASIL DAN PEMBAHASAN Aspek Kognitif}

Nilai rata-rata pretest yang diperoleh pada sikius I sebesar 56,26 sedangkan nilai rata-rata post test sebesar 66.36. Hal itu rnenunjukkan bahwa terjadi peningkatan basil belajar siswa sebesar 10,10. Nilai pre test siklus I ketahui bahwa siswa yang mengalami ketuntasan dalam belajar sebanyak 5 siswa dengan persentase $17,86 \%$ dan yang belum tuntas dalam belajar sebanyak 23 siswa dengan persentase $82,14 \%$. Nilai post test diketahui bahwa siswa yang tuntas belajar sebanyak 16 siswa dengan persentase $57,14 \%$ siswa yang belum tuntas belajar sebanyak 12 siswa dengan persentase $42,86 \%$. Dapat dilihat bahwa hasil belajar siswa meningkat setelah implementasi pembelajaran kooperatif model two stay two stray (TSTS). Peneliti dan para pengamat menganalisis kelemahan dan keberhasilan guru saat menerapkan pembelajaran kooperatif model two stay two stray (TSTS), dan mempertimbangkan langkah selanjutnya. Terutama dalam mengelola kelas, saat siswa melakukan kerja kelompok. Guru melakukan refleksi terhadap penerapan pembelajaran kooperatif model two stay two stray (TSTS), pada pokok bahasan keaneragaman makluk hidup. Selama diskusi kelas guru berusaha berkeliling pada setiap kelompok. Guru menanyakan kesulitan atau masalah yang dihadapi saat melakukan kegiatan pembelajaran. Guru dibantu peneliti melakukan refleksi terhadap kreativitas siswa dalam pembelajaran IPA/Sains, kreativitas dan hasil evaluasi siswa meningkat setelah mengalami pembelajaran yang dilaksanakan guru. Siswa terlibat aktif dalam diksusi kelompok. Guru melakukan refleksi terhadap hasil belajar siswa, mengevaluasi terhadap kekurangan dan kelemahannya dalam pelaksanaan pembelajaran, berupaya untuk memperbaikinya. Pada siklus II hasil belajar siswa dan aspek kognitif juga mengalami pingkatan. Nilai rata-rata pretest siswa sebelum diterapkan pembelajaran mode1 two stay two stray (TSTS) adalah 59,32 dan jumlah siswa yang tuntas belajar sebanyak 8 siswa dengan persentase $28,57 \%$ sedangkan jumlah siswa yang belum tuntas belajar sebanyak 20 siswa dengan persentase $71,43 \%$. Pada siklus I guru masih ragu dalam menerapkan kooperatif tipe two stay two stray.

Setelah diterapkan pembelajaran kooperalif model Two stay two stray (TSTS), nilai rata-rata post test siswa meningkat menjadi 76.42 dan jumlah siswa yang tuntas belajar banyak 24 siswa dengan persentase $85,71 \%$ sedangkan siswa yang belurn tuntas belajar sebanyak 4 siswa dengan persentase $14,29 \%$. Itu berarti bahwa hasil belajar siswa mengalami peningkatan sebesar 71,42. 
Tabel 1. Rekapitulasi nilai pembelejaran IPA pada siklus I dan siklus II

\begin{tabular}{|c|c|c|c|c|}
\hline ż & 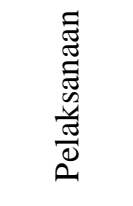 & 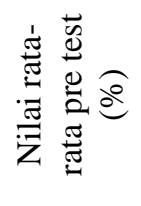 & 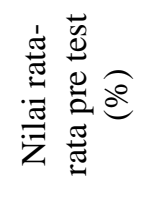 & 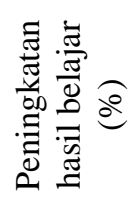 \\
\hline 1. & Siklus I & 56,26 & 66.36 & 10,10 \\
\hline 2. & Siklus II & 59,32 & 76.42 & 17,10 \\
\hline
\end{tabular}

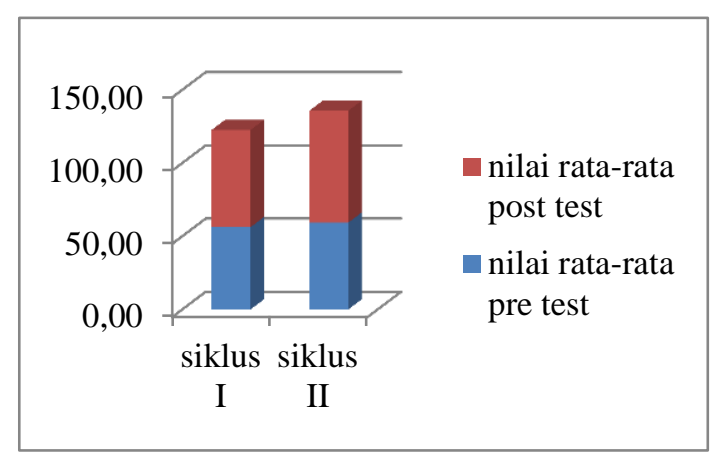

Gambar 1. Grafik Hasil Belajar Siswa Pada Siklus I dan Siklus II

\section{Aspek Afektif}

Penilaian hasil belajar ditinjau dan aspek afektif pada siklus I ketahui bahwa siswa yang tuntas belajar sebanyak 20 siswa $(71,43 \%)$ sedangkan siswa yang belum tuntas belajar sebanyak 8 siswa $(28,57 \%)$. Pada siklus I siswa belum sepenuhnya bisa kerjasama dalam kelompoknya, beberapa siswa masih mendominasi kerja sehingga siswa yang lain banyak yang diam dan hanya menunggu jawaban dan temannya. Kemampuan berkomunikasi siswa juga masih kurang, hal itu terlihat saat kegiatan diskusi dengan kelompoknya, mengajukan pertanyaan, saran, kritik, tanggapan maupun sanggahan di depan kelas. Tingkat kejujuran siswa dalam mengerjakan test masih rendah, masih banyak siswa yang bertanya dan bekerjasama dengan temannya ataupun berusaha untuk membuka buku.

Setelah dilakukan perbaikan pada siklus II diketahui siswa yang tuntas belajar sebanyak 27 siswa $(96,4 \%)$ sedangkan siswa yang belum tuntas belajar sebanyak 1 siswa (3,57\%). Peningkatan hasil belajar siswa aspek afektif ditandai oleh beberapa hal antara lain siswa sudah mampu bekerjasama dalam kelompoknya, sudah terjadi pembagian kerja yang baik, sudah mau menghargai masukan atau pendapat dari teman sekelompoknya, siswa sudah dapat berkomunikasi dengan kalimat yang baik pada saat berdiskusi dengan kelompoknya, mengajukan pertanyaan, saran, kritik ataupun tanggapan di depan kelas. Tingkat kejujuran siswa juga mengalami peningkatan telihat dan percayaan diri siswa saat mengerjakan tes.

\section{Hambatan Yang Muncul Selama Diterapkannya Pembelajaran Kooperatif Model Two stay two stray (TSTS)}

- Pada awalnya dalam mendesain pembelajaran kooperatif model Two stay two stray (TSTS), pada pokok bahasan keaneragaman mahluk hidup untuk mata pelajaran IPA, guru awalnya masih ragu dan belum terbiasa. Dalam menerapkan pembelajaran kooperatif model Two stay two stray (TSTS) masih mengalami kesulitan dalam pengelolaan waktu. Belum dapat membagi waktu dalam masing-masing kegiatan pembelajaran.

- Pada awalnya siswa mengalami kesulitan bekerja dalam kelompok, terutama siswa yang pintar/pandai tidak mau bergabung dengan siswa yang tidak/kurang pandai. Siswa yang merasa dirinya pandai lebih suka belajar dan bekerja sendiri. Siswa terkesan egois, untuk dapat menyatukan siswa dalam kelompok dan bekerja sama guru berusaha memberi penjelasan tentang pentingnya berbagi, bekerja sama, bersahabat tanpa memperhatikan kepintaran atau kemampuan orang lain. Justru siswa yang memiliki kelebihan daripada teman-temannya 
dapat membantunya dengan memberikan penjelasan tentang teori/materi pelajaran yang belum dipahami dan dimengerti.

- Kurangnya rasa kepercayaan diri siswa saat diskusi kelas berlangsung. Sebagian besar siswa masih belum beranimengungkapkan ide atau pendapatnya di depan kelas.

\section{KESIMPULAN}

1. Pembelajaran kooperatif model Two stay two stray (TSTS) dapat meningkatkan prestasi belajar siswa pada pokok bahasan keanekaragaman mahluk hidup di SMP Plus Miftahul Ulum Tarate Sumenep

2. Kinerja belajar siswa meningkat dengan menggunakan pembelajaran kooperatif model Two stay two stray (TSTS).

\section{SARAN}

1. Penelitian tindakan kelas yang dilakukan bertujuan adalah memperbaiki pembelajaran yang dilaksanakan guru menggunakan pembelajaran kooperatif model Two stay two stray (TSTS), dapat dijadikan alternatif untuk penelitian tindakan kelas yang akan dilaksanakan berikutnya.

2. Dalam pelaksanaan pembelajaran guru selain sebagai fasilitator juga sebagai motivator sehingga guru hendaknya dapat terus memberi motivasi kepada siswa agar siswa dapat berperan aktif dalam pembelajaran.

\section{DAFTAR PUSTAKA}

Aqip, Z. 2006. Penelitian Tindakan Kelas. Jakarta: Yrama Widya.

Abdullah. 2008. Prestasi Belajar. (online) (http://spesialistorch.com/content/view/120/29/), diakses 5 Agustus 2013.
Ali, M. 1984. Guru Dalam Proses belajar Mengajar. Bandung: Sinar Baru.

Arikunto, dkk. 2007. Penelitian Tindakan Kelas. Jakarta: PT Bumi Aksara.

Bektiarso,S. 1997. Pengembangan Konsep Siswa. Majalah Ilmiah Pancaran Pendidikan Th. X No 38. Jember: FKIP Unej.

Dimyati dan Mudjiono. 2002. Belajar dan Pembelajaran. Jakarta: Rineka Cipta.

Hamalik, O. 2004. Proses Belajar Mengajar. Jakarta: PT Bumi Aksara.

Ibrahim, dkk. 2000. Pembelajaran Kooperatif. Surabaya: UNESA_University Press.

Kunandar. 2008. Langkah Mudah PTK Sebagai Pengembangan Profesi Guru. Jakarta: PT Raja Grafindo Persada.

Marsandi, W. 1978. Belajar Tuntas (Mastery Learning). Jakarta: Departemen Pendidikan dan Kebudayaan. BP3K.

Sudjana, Nana. 2009. Penilaian Hasil Proses Belajar Mengajar. Bandung: PT. Remaja Rosdakarya.

Suprijono, Agus. 2009. Cooperatif Learning Teori dan Aplikasi Paikem. Yokyakarta: Pustaka Belajar.

Sagala. 2003. Konsep Dan Makna Pembelajaran. Bandung: Alfabeta.

Slavin, R. E. 2008. Cooperative Learning Teori, Riset dan Praktek. Jakarta: Nusamedia

Sugiono. 2005. Memahami Penilaian Kualitatif. Bandung: CV Alfabeta. 
Jurnal Lentera Sains (Lensa)

8 Jurnal Lensa, Volume 5 Jilid II November 2015 
